\title{
Increased capacity of urea synthesis in streptozotocin diabetes in rats
}

\author{
T.P. Almdal, K. F. Petersen, B. A. Hansen and H. Vilstrup \\ Divisions of Hepatology and Experimental Pathology, Rigshospitalet, Copenhagen, Denmark
}

\begin{abstract}
Summary. Diabetes was induced in Wistar rats by intravenous streptozotocin, $75 \mathrm{mg} / \mathrm{kg}$. Four and 14 days after streptozotocin, fasting insulin decreased to about one-third, and fasting glucagon increased three-fold. The urea- $\mathrm{N}$ synthesis rate, stimulated by infusion of alanine, was measured at different amino acid concentrations 14 days after streptozotocin in 24 rats. The relationship was compatible with a barrier limited substrate inhibition kinetics. Data were examined accordingly by non-linear regression analysis. Among the estimated kinetic constants, only the 70\% increase in Vmax was different from control values. In control rats the capacity of urea nitrogen synthesis, as measured within the amino acid concentration interval $7.3-11.6 \mathrm{mmol} / \mathrm{l}$, was $10.2 \pm 1.1 \mu \mathrm{mol} \cdot(\mathrm{min} 100 \mathrm{~g}$
\end{abstract}

BW $)^{-1}$ (mean \pm SEM). The capacity was not different in 4 day diabetic rats, whereas it doubled in 14 day diabetic rats, $20.9 \pm 1.7 \mu \mathrm{mol}\left(\mathrm{min} 100 \mathrm{~g} \mathrm{BW}^{-1}\right.$. The alanine elimination rate was $35 \%$ higher in the 14 day diabetic rats compared both to 4 day diabetic and control rats. The increase of urea synthesis is suggested to be due to enzyme induction by glucagon. The net nitrogen balance was negative at amino acid concentrations up to $25 \mathrm{mmol} / \mathrm{l}$, indicating that the urea synthesis was increased at the expense of amino nitrogen.

Key words: Urea, experimental diabetes, nitrogen conversion, hyperglucagonaemia.
Diabetes mellitus is characterized by hypoinsulinaemia and hyperglucagonaemia. The latter phenomenon has attracted increasing interest during the last decade.

Animal and human studies have shown that glucagon increases the activity of the urea cycle enzymes [1, 2]. The activity of urea cycle enzymes is increased in experimental diabetes [3]. In normal man suppression of glucagon by glucose is followed by a decrease in the urea synthesis rate [4], and in diabetic patients suppression of glucagon by somatostatin is followed by a decrease in the urinary urea output [5].

On this basis it is conceivable that the kinetics of urea synthesis in hyperglucagonaemic diabetic rats is changed so that more than normal urea is synthetised. To test this hypothesis it is necessary to study the urea synthesis rate under standardized conditions, e.g. as the alanine stimulated capacity of urea-N synthesis.

The aim of the present work was to study changes in the kinetics of alanine-stimulated urea synthesis in streptozotocin diabetic rats.

\section{Materials and methods}

\section{Animals}

Female Wistar rats with an average body weight of $220 \mathrm{~g}$ (range $190-240 \mathrm{~g}$ ) were kept in a thermostated room with a fixed $12 \mathrm{~h}$ artificial light/dark cycle and fed ad libitum with stock rat pellets and tap water. After an overnight fast one group of animals was given streptozotocin intravenously (Zanosar, Upjohn Co, Kalamazoo, Mich, USA), $75 \mathrm{mg} / \mathrm{kg}$ body weight, dissolved in isotonic saline acidified to $\mathrm{pH}$ 4.5. The control animals were given isotonic saline acidified to pH 4.5. Studies were performed after 4 days ( 4 control rats, 7 diabetic rats) and after 14 days ( 5 control rats, 24 diabetic rats). The criterion for diabetes was fasting blood glucose concentration $>9.5 \mathrm{mmol} / \mathrm{l}$ on the day of investigation.

\section{Experimental procedures}

After $14 \mathrm{~h}$ of fasting with free access to water, the animals were anaesthetised with thiopental $(50 \mathrm{mg} / \mathrm{kg}$ body weight intraperitoneally), followed by tracheotomy, intubation, nephrectomy and venous and arterial catheterization for infusion and blood sampling, respectively, as described earlier [6]. Alanine was administered as a bolus injection of $0.90-2.25 \mathrm{mmol}$ alanine followed by a constant infusion for $100 \mathrm{~min}$ of $10.5-33.6 \mu \mathrm{mol}$ alanine/min by means of a roller pump (Perfusor Secura, Braun, Melsungen, FRG). Steady state amino acid concentration was defined as less than $10 \%$ change during at least $50 \mathrm{~min}$.

In a separate study, $24 \mathrm{~h}$ urine production, blood urea concentration and creatinine clearance were determined in 5 fasted and 5 nonfasted 14 day diabetic rats.

\section{Sampling procedures}

For determination of blood urea and total alpha-amino- $N$ concentration, samples of $50 \mu \mathrm{l}$ of arterial blood were taken before the amino acid infusion was started and after an equilibration period of $20 \mathrm{~min}$ at intervals of $10 \mathrm{~min}$. For determination of blood glucose, plasma insulin and glucagon concentrations, samples were taken before starting 
Table 1. Change in body weight from the day of injection of streptozotocin/placebo to the day of investigation, and fasting concentrations of blood glucose, alpha-amino- $\mathrm{N}$, urea- $\mathrm{N}$ and plasma insulin and glucagon on the day of investigation in control rats, 4 day and 14 day diabetic rats

\begin{tabular}{llcc}
\hline & $\begin{array}{l}\text { Control } \\
\text { rats } \\
(n=9)\end{array}$ & $\begin{array}{l}\text { 4 day } \\
\text { diabetic rats } \\
(n=7)\end{array}$ & $\begin{array}{l}\text { 14 day } \\
\text { diabetic rats } \\
(n=24)\end{array}$ \\
\hline $\begin{array}{l}\text { Change in } \\
\text { body weight } \\
\text { (g) }\end{array}$ & $+17.8 \pm 1.3^{\mathrm{a}}$ & $-24.6 \pm 3.9$ & $-33.0 \pm 3.0$ \\
$\begin{array}{c}\text { Blood glucose } \\
\text { (mmol/1) }\end{array}$ & $4.4 \pm 0.3$ & $13.4 \pm 0.3$ & $14.2 \pm 0.5$ \\
$\begin{array}{l}\text { Blood alpha- } \\
\text { amino-N } \\
(\text { mmol/1) }\end{array}$ & $5.7 \pm 0.4$ & $5.7 \pm 0.3$ & $5.4 \pm 0.3$ \\
$\begin{array}{c}\text { Blood urea-N } \\
(\text { mmol/1) }\end{array}$ & $16.7 \pm 1.4$ & $17.94 \pm 1.9$ & $41.5 \pm 3.0$ \\
$\begin{array}{c}\text { Plasma insulin } \\
(\mathrm{mU} / 1)\end{array}$ & $27 \pm 3$ & $6 \pm 1$ & $10 \pm 1$ \\
$\begin{array}{c}\text { Plasma glucagon } \\
(\mathrm{ng} / \mathrm{l})\end{array}$ & $241 \pm 71$ & $823 \pm 64$ & $731 \pm 85$ \\
\hline
\end{tabular}

Results are given as mean \pm SEM. ${ }^{\text {a }}$ This value only represents the weight gain of 14 day control rats, whereas the rest of the values in the control group represent both 4 day and 14 day control rats since they showed identical values

the infusion, at 20 and $100 \mathrm{~min}$ later. A total of $900 \mu \mathrm{l}$ of blood was removed. This was compensated by infusion of alanine.

The fraction of newly synthetised urea lost in the gut by bacterial hydrolysis (L), determined by a 14-C-urea tracer method [7] in diabetic animals 14 days after streptozotocin injection, was $25 \pm 5$ percent (mean \pm SEM). This is not different from the value of 20 percent found in normal rats [6]. The latter value was used in the present study.

The volume of distribution of urea $\left(V_{D}\right)$ was determined by an intravenous bolus injection (D) of about $1 \mathrm{mmol}$ of urea. The blood urea concentration was then followed for $80 \mathrm{~min}$. After $20 \mathrm{~min}$ the distribution of urea was completed; the slope of the regression analysis of urea concentration on time was not significantly different from zero. The volume of distribution was calculated as: $V_{D}=\left(c_{0}-c_{i}\right)$, where $D$ is the amount of urea injected, $c_{o}$ the mean blood urea concentration in the interval 20-80 min after injection of urea and $c_{i}$ the blood urea concentration at time immediately before injection of urea. $V_{D}$ in relation to body weight was the same in control and diabetic rats: $65 \pm 2$ percent and $61 \pm 2$ percent respectively (mean $\pm S D$, $n=4)$. Neither of these values are different from the 63 percent found earlier [6]. The last value was used in all the present calculations.

\section{Analyses}

The blood urea concentration was measured by the urease Berthelot method [8], total blood alpha-amino-nitrogen concentration by the dinitrofluorobenzene method [9] and blood glucose by the glucose oxydase technique using a rapid glucose determination apparatus (Yellow Springs Instruments Co, Yellow Springs, Ohio, USA). Insulin and glucagon were determined by radioimmunoassay [10], and glucagon after extraction by ethanol precipitation according to Heding [11].

\section{Calculations}

The urea N synthesis rate $(\mathrm{UNSR})\left(\mu \mathrm{mol} \cdot\left(\min 100 \mathrm{~g} \mathrm{BW}^{-1}\right)\right.$ was calculated as:

$$
\mathrm{UNSR}=\mathrm{d}\left(\mathrm{c}_{12}\right) / \mathrm{d}(\mathrm{t}) \cdot 0.63 \mathrm{BW} \cdot(1 /(1-\mathrm{L}))
$$

where $d\left(c_{k}\right) / d(t)$ is the slope of the linear regression of arterial blood urea- $\mathrm{N}$ concentration on time during steady state, $0.63 \mathrm{BW}$ is the volume of distribution of urea [12], and $\mathrm{L}$ is the fraction of newly synthesized urea lost in gut by hydrolyse $(0.20)$. In the 14 day diabetic rats the relation between UNSR and blood amino acid nitrogen concentration $\left(c_{a}\right)$ was examined in a barrier limited substrate inhibition model [13] as:

$$
\mathrm{v}=\operatorname{Vmax}\left(\mathrm{c}_{\mathrm{a}}-\beta\right) /\left(\mathrm{K}_{\mathrm{m}}+\left(\mathrm{c}_{\mathrm{a}}-\beta\right)+\left(\mathrm{c}_{\mathrm{a}}-\beta\right)^{2} / \mathrm{K}_{\mathrm{i}}\right)
$$

where Vmax is the maximum velocity, $\mathrm{K}_{\mathrm{m}}$ is the affinity constant, $\mathrm{K}_{\mathrm{i}}$ is the inhibition constant and $\beta$ the barrier (the amino acid concentration below which the urea synthesis ceases).

The parameters and their uncertainties were examined by non-linear iterative regression analysis of $v$ on $c_{a}$, subject to the constraints given by the model [14]. The experimental variation of determinations of the urea nitrogen synthesis rate did not depend on $c_{a}$, and therefore data were processed unweighted. The residuals between observed and predicted urea synthesis rates had no systematic trend. The experimental data thus are accepted by the proposed kinetic model. Urea nitrogen synthesis rate measured in the interval $7.3-11.6 \mathrm{mmol} / 1$ represents the capacity of urea- $\mathrm{N}$ synthesis [6].

The rate of whole body alanine elimination $\left(E_{a}\right)(\mu \mathrm{mol} \cdot(\min 100 \mathrm{~g}$ $\mathrm{BW})^{-1}$ ) within the amino acid concentration interval 7.3-11.6 mmol/1 was calculated as:

$$
\mathrm{E}_{\mathrm{a}}=\mathrm{I}_{\mathrm{a}}-\left(\mathrm{d}\left(\mathrm{c}_{\mathrm{a}}\right) / \mathrm{d}(\mathrm{t}) \cdot 0.50 \mathrm{BW}\right)
$$

where $I_{a}$ is the alanine infusion rate, $d\left(c_{a}\right) / d(t)$ is the slope of the linear regression of arterial blood alpha-amino- $\mathrm{N}$ concentration on time (not systematically different from zero), and $0.50 \mathrm{BW}$ the volume of distribution of alanine [15].

The net nitrogen balance (Nbal) for 14 day diabetic rats was calculated as:

$$
\mathrm{Nbal}=\left(\mathrm{I}_{\mathrm{a}}-\left(\mathrm{d}\left(\mathrm{c}_{\mathrm{a}}\right) / \mathrm{d}(\mathrm{t}) 0.50 \mathrm{BW}\right)-\left(\mathrm{d}\left(\mathrm{c}_{\mathrm{u}}\right) / \mathrm{d}(\mathrm{t}) 0.63 \mathrm{BW}\right)\right.
$$

notations as above, $d\left(c_{u}\right) / d(t) \cdot 0.63 \mathrm{BW}$ is the accumulation of urea nitrogen.

\section{Statistical analysis}

Results are given as mean \pm standard error of the mean (SEM). Differences among groups were assessed by one-way analyses of variance, and between groups by Student's $t$-tests.

\section{Results}

The fasting insulin concentration was reduced to $20-30 \%$ of the control value in both 4 and 14 day diabetic animals $(p<0.01)$ (Table 1$)$. The fasting glucagon concentration increased four-fold in both groups of diabetic animals $(p<0.01)$.

The 14 day diabetic animals lost 15 percent body weight (Table 1), whereas the control animals gained up to 10 percent. The blood glucose concentration was elevated three-fold in the streptozotocin treated rats. There was no difference in the fasting blood concentration of total alpha amino-N. The fasting blood concentration of urea- $\mathrm{N}$ in 4 day diabetic animals was not significantly different from that of the controls, whereas the blood urea- $\mathrm{N}$ concentration in the fasted 14 day diabetic animals doubled.

In the 5 fasted and in the 5 non-fasted 14 day diabetic rats, the creatinine clearance was identical: $0.90 \pm$ $0.13 \mathrm{ml} / \mathrm{min}$, which is normal [16]. Non-fasted 14 day diabetic rats had a urine production of $88 \pm 4 \mathrm{ml} / 24 \mathrm{~h}$ (mean $\pm \mathrm{SEM}$ ) and a normal blood urea- $\mathrm{N}$ concentra- 


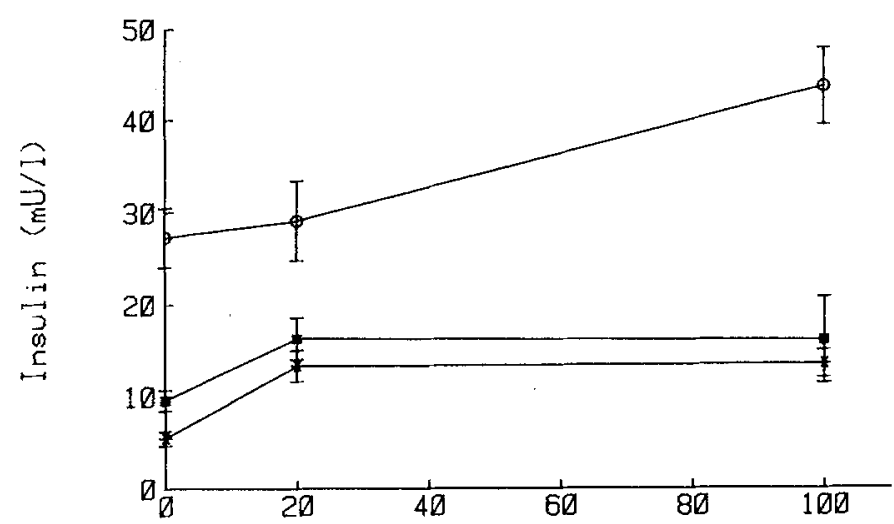

a

Time (min)

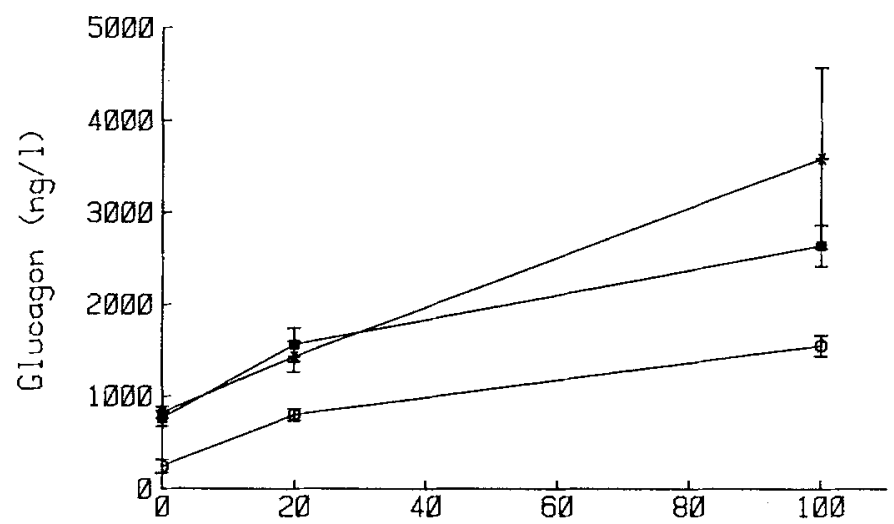

b

Time (min)

Fig.1 a Relationship between insulin concentration and time after start of experiment in control rats $(n=9), 4$ day diabetic rats $(n=7)$ and in 14 day diabetic rats $(n=24)$. Symbols, $\mathrm{O}-\mathrm{O}$ controls; *-* 4 day; 14 day, indicate mean and bars indicate SEM. b Relationship between glucagon concentration and time after start of experiments in control rats $(n=9), 4$ day diabetic rats $(n=7)$, and 14 day diabetic rats $(n=24)$. Symbols indicate mean and bars indicate SEM

tion of $22.4 \pm 1.8 \mathrm{mmol} / 1$. In the fasted rats the urine production was $24 \pm 3 \mathrm{ml} / 24 \mathrm{~h}$, and the blood urea-N concentration was doubled to $47.6 \pm 5.2 \mathrm{mmol} / 1$.

The infusion of alanine increased the plasma insulin concentration by about 50 percent in all groups (Fig. $1 \mathrm{a})$, but in the diabetic animals it remained below the fasting levels of the controls. The infusion of alanine increased the plasma glucagon concentration four-fold in all groups (Fig. $1 \mathrm{~b}$ ).

In the 14 day diabetic rats, the urea- $\mathrm{N}$ synthesis rate (Fig. 2) rose rapidly with increasing amino acid concentrations, reached a maximum of $17-23 \mu \mathrm{mol} \cdot(\min 100 \mathrm{~g}$ $\mathrm{BW})^{-1}$ at about $9 \mathrm{mmol} / \mathrm{l}$, and declined at higher concentrations.

The assessed values of the kinetic parameters of the relation between the urea nitrogen synthesis rate and the amino acid concentration, as examined in a barrier limited substrate inhibition model, were (mean $\pm \mathrm{SD})$ :
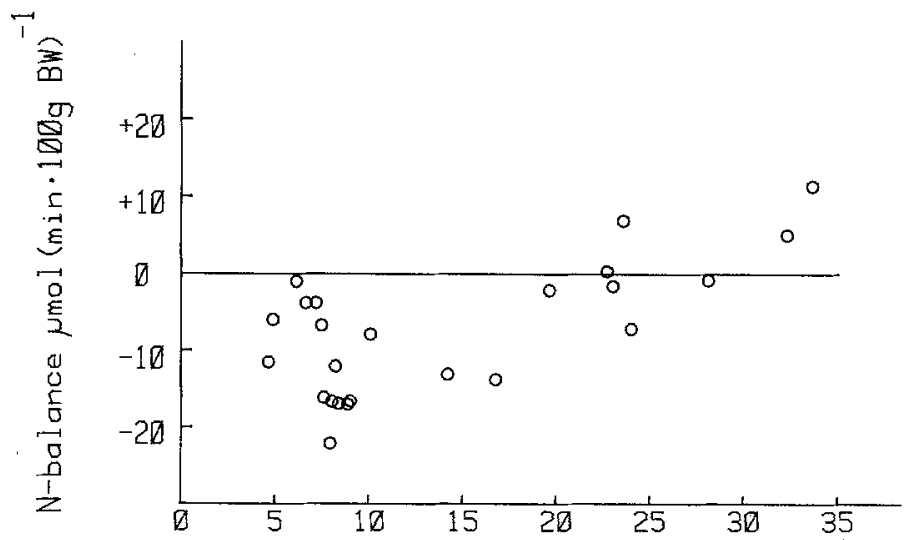

Tatal alpha-amino-N (mmol/1)

Fig. 2. Relationship between urea nitrogen synthesis rate (UNSR) and total alpha-amino- $\mathrm{N}$ concentration in 14 day diabetic rats. Each point represents one animal

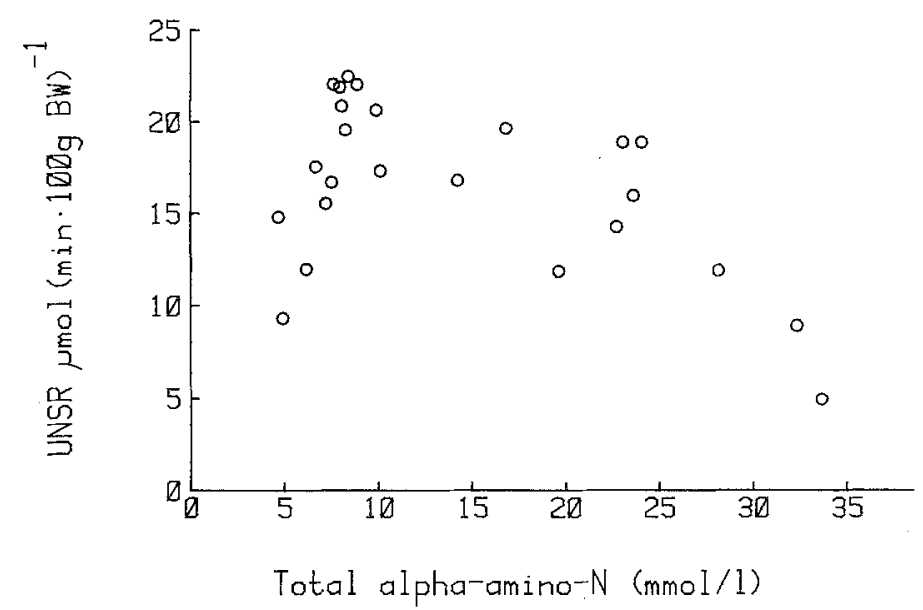

Fig. 3. Relationship between nitrogen balance (Nbal) and total arterial blood alpha-amino- $\mathrm{N}$ concentration in 14 day diabetic rats. Each symbol represents one animal

Table 2. The Capacity of Urea Nitrogen Synthesis (CUNS) and the alanine elimination rate $\left(E_{a}\right)$ in control rats, 4 day and 14 day diabetic rats

\begin{tabular}{llll}
\hline & $\begin{array}{l}\text { Control } \\
\text { rats } \\
(n=9)\end{array}$ & $\begin{array}{l}4 \text { day } \\
\text { diabetic rats } \\
(n=7)\end{array}$ & $\begin{array}{l}\text { 14 day } \\
\text { diabetic rats } \\
(n=8)\end{array}$ \\
\hline CUNS & $10.2 \pm 1.1$ & $11.0 \pm 3.5$ & $20.9 \pm 1.7$ \\
$\mathrm{E}_{\mathrm{a}}$ & $6.3 \pm 0.2$ & $6.4 \pm 0.1$ & $8.6 \pm 0.4$ \\
\hline
\end{tabular}

Results are $\mu \mathrm{mol} \cdot\left(\min 100 \mathrm{~g} \mathrm{BW}^{-1}\right.$ given as mean $\pm \mathrm{SEM}$

Vmax: $32.8 \mu \mathrm{mol} \cdot(\min 100 \mathrm{~g} \mathrm{BW})^{-1}, \mathrm{~K}_{\mathrm{m}}: 1.2 \pm$ $0.7 \mathrm{mmol} / 1, \quad \mathrm{~K}_{\mathrm{i}}: 14.0 \pm 6.2 \mathrm{mmol} / 1$ and the barrier: $5.4 \pm 0.1 \mathrm{mmol} / 1$.

The capacity of the urea-N synthesis did not differ from control values 4 days after streptozotocin injection (Table 2), but doubled 14 days after streptozotocin $(p<0.01)$. 
The average alanine elimination rate $\left(\mathrm{E}_{\mathrm{a}}\right)$ constituted about 60 percent of the urea- $\mathrm{N}$ synthesis (Table 2) in the control animals. It was unchanged after 4 days, but increased by 35 percent 14 days after streptozotocin $(p<0.01)$.

The net nitrogen balance of 14 day diabetic rats was negative at amino acid concentrations up to about $25 \mathrm{mmol} / 1$ (Fig. 3).

\section{Discussion}

The results show that diabetes in rats doubles the capacity of urea nitrogen synthesis in 14 days. Such animals produced two times as much urea as normal rats at a given amino acid concentration [6].

The fasted 14 day diabetic rats had a high basal concentration of urea- $\mathrm{N}$, whereas it was normal in non-fasted rats. The kidney function of both fasted and nonfasted 14 day diabetic rats was normal. The difference in blood urea- $\mathrm{N}$ concentration is thus explained by the differences in urine flow, as the fraction of excreted urea increases with increasing urine flow [17].

The hyperglycaemia is not responsible for the increased urea synthesis. Using the clamp technique in normal rats, hyperglycaemia has been shown to decrease the capacity of urea- $\mathrm{N}$ synthesis [18]. In normal man glucose decreases the urea synthesis, probably via a suppression of glucagon [4].

The role of insulin is not clear. High insulin concentrations in themselves immediately decrease the capacity of the urea-N synthesis [18]. The doubled capacity of urea- $\mathrm{N}$ synthesis in this study is not likely to be explained by the hypoinsulinaemia that was already present 4 days after streptozotocin, and where the urea synthesis was normal.

In this study the theoretical Vmax was $32.8 \mu \mathrm{mol}$. $\left(\min 100 \mathrm{~g} \mathrm{BW}^{-1}\right.$, which is 70 percent higher $(p<$ $0.001)$ than that of normal rats: $19.3 \mu \mathrm{mol} \cdot(\min 100 \mathrm{~g}$ $\mathrm{BW})^{-1}$, whereas the other kinetic constants were normal [6]. Since Vmax usually is taken to reflect the amount of active enzyme, this suggests enzyme induction. Accordingly, the amounts of urea cyclus enzymes are increased in experimental diabetes [3] and in rats pretreated with glucagon [1]. In rats given exogenous glucagon for one week, we have earlier found that the capacity of urea nitrogen synthesis increases [20]. After 14 days of glucagon treatment the capacity is similar to that found in the present 14 day diabetic rats. Thus, as the diabetic rats showed a marked hyperglucagonaemia after both 4 and 14 days, the increased capacity of urea- $\mathrm{N}$ synthesis in diabetes is consistent with a induction of the urea cyclus enzymes by the hyperglucagonaemia.

In the post absorptive state there is a net peripheral release of alanine [21]. The changes in alanine metabolism, i. e. removal of alanine from the blood 14 day after streptozotocin, therefore primarily reflect changes in the splanchnic uptake of alanine. The excess in urea-N synthesis in relation to the metabolism of exogenous alanine is ascribable to the incorporation into urea of endogenous alanine- $\mathrm{N}$, non alanine amino- $\mathrm{N}$, amide- $\mathrm{N}$ of glutamine, and ammonia. This excess more than doubled 14 days after streptozotocin, which means that the relative increase in non-alanine derived capacity of urea- $\mathrm{N}$ synthesis is greater than the increase in the alanine derived capacity urea- $\mathrm{N}$ synthesis. It is not known to which extent this is due to changed hepatic kinetics of urea synthesis, or whether it is secondary to increased peripheral release of nitrogenous precursors.

However, the normal fasting alpha-amino- $\mathrm{N}$ concentrations in the diabetic rats makes it less probable that changed urea kinetics is the only explanation, since this would lead to depletion of the free amino acid pool.

The 12 percent loss in body weight of the 14 day diabetic rats is partly explainable by dehydration because of osmotic diuresis. The animals were fed ad libitum and they were not reluctant to eat or drink. Therefore the further weight loss of $1 \mathrm{~g} /$ day of the 14 day diabetic rats, compared with the increase of $1 \mathrm{~g} /$ day in control rats, can be taken to reflect a waste of body mass. Accordingly, the nitrogen balance of the diabetic rats was negative up to amino acid concentrations of approximately $25 \mathrm{mmol} / 1$, whereas the nitrogen balance of normal rats [6] was positive above amino acid concentrations of about $10 \mathrm{mmol} / \mathrm{l}$.

The present study shows that the urea synthesis rate increases independently of the blood amino acid concentration in uncontrolled diabetes. This is suggested to be due to induction of the urea cycle enzymes by the hyperglucagonaemia. The nitrogen homeostasis is changed towards increased hepatic elimination of nitrogen and increased peripheral release of nitrogenous substances. This is in favour of a negative nitrogen balance, partly because of changes occurring within the hepatocytes.

Acknowledgments. The conscientious and skillful technical assistance of B Krog, K Prisholm, and L Hansen is hereby gratefully acknowledged. Our thanks are due to NOVO, Denmark, who supplied iodinated insulin and glucagon, and antisera. The investigation was supported by grants from the Danish Medical Research Council (12-4211, 12-2253), the Danish Foundation for Advancement of Medical Science, and the Research Foundation of the Danish Medical Association.

\section{References}

1. Snodgrass PJ, Lin RC, Muller WA, Aoki TT (1978) Induction of urea cycle enzymes of rat liver by glucagon. J Biol Chem 253: 2748-2753

2. Wolfe BM, Culebras JM, Aoki TT, O Connor NE, Finley RJ, Kaczowka A, Moore FD (1979) The effects of glucagon on protein metabolism in normal man. Surgery $86: 248-257$

3. Mclean P, Novello F (1965) Influence of Pancreatic Hormones on Enzymes concerned with Urea Synthesis in Rat Liver. Biochem J 94: 410-421 
4. Vilstrup H (1984) Effects of glucose on alanine derived urea synthesis. Clin Physiol 4: 495-507

5. Raskin P, Unger R (1978) Hyperglucagonemia and its suppression. Importance in metabolic control of diabetes. N Engl J Med 299: 433-436

6. Hansen BA, Vilstrup H (1985) A method for determination of the capacity of urea synthesis in the rat. Scand J Clin Lab Invest 45: 315-320

7. Walser M, Bodenloss LJ (1959) Urea metabolism in man. J Clin Invest 38: 1617-1626

8. Fawcett JK, Scott JE (1960) A rapid and precise method for determination of urea. J Clin Pathol 13: 156-159

9. Goodwin JF (1970) Spectophotometric quantitation of plasma and urinary amino nitrogen with flurodinitrobenzene. Stand Meth Clin Chem 6: 89-98

10. Ørskov $H$, Yde $H$, Thomsen HC (1968) Wick-chromatography for rapid and reliable immuno-assay of insulin, glucagon and growth hormone. Nature 219: 1993-1995

11. Heding LG (1971) Radioimmunological determination of pancratic and gut glucagon in plasma. Diabetologia 7:10-17

12. Foy J, Schnieden H (1960)Estimation of total body water (virtual tritium space) in the rat, cat, rabbit, guinea-pig and man, and of the biological halflife of tritium in man. J Physiol 154: 169-176

13. Segel IH (1975) Enzyme kinetics. John Wiley \& Sons, New York

14. Rao CR (1975) Linear statistical inference and its applications. Wiley-Interscience, New York

15. Pietro AS, Rittenberg D (1953) A study of the rate of protein synthesis in humans. J Biol Chem 201: 445-455
16. Jensen PK, Sandahl Christiansen J, Steven K, Parving HH (1981) Renal function in Streptozotocin-diabetic rats. Diabetologia 21: 409-414

17. Shanon JA (1938) Urea excretion in the normal dog during forced diuresis. Am J Physiol 122: 782-787

18. Hansen BA, Krog B, Vilstrup H (1986) Effect of insulin on the capacity of urea synthesis and whole body alanine and glucose metabolism in intact rats. Scand J Clin Lab Invest 46:599-603

19. Hansen JA, Vilstrup H (1985) Kinetics of urea synthesis and alanine uptake by perfused rat livers. Liver $5: 1-7$

20. Petersen KF, Hansen BA, Vilstrup H (1986) Time dependent stimulatory effect of glucagon on the capacity of urea synthesis in rats. Hormone and Metabolic Research (in press)

21. Wahren J, Felig P, Luft R (1972) Splanchnic and peripheral glucose and amino acid metabolism in diabetes mellitus. J Clin Invest 51: $1870-1878$

Received: 3 June 1986

and in revised form: 23 September 1986

Thomas Peter Almdal, MD

Rigshospitalet A-2151

9 Blegdamsvej

DK -2100 Copenhagen

Denmark 